\title{
MORPHYLL: \\ A database of fossil leaves and their morphological traits
}

\author{
Christopher Traiser, Anita Roth-Nebelsick, Michaela Grein, Johanna Kovar-Eder, \\ Lutz Kunzmann, Karolin Moraweck, Jörg Lange, Jiří Kvaček, Christoph Neinhuis, \\ Annelise Folie, Dario De Franceschi, Andreas Kroh, Cyrille Prestianni, \\ Markus Poschmann, and Michael Wuttke
}

\begin{abstract}
Morphometric characters of fossil leaves such as size and shape are important and widely used sources for reconstructing palaeoenvironments. Various tools, including CLAMP or Leaf Margin Analysis, utilize leaf traits as input parameters for estimating palaeoclimate, mostly based on correlations between traits and climate parameters of extant plants. During the last few years, the scope of information extracted from the morphology of fossil leaves has been further expanded by including leaf economics, which describe correlations between functional leaf traits and ecological strategies. The amount and quality of available data are essential for a successful palaeoecological analysis utilizing leaf traits. Here, the database MORPHYLL is described. This database is devised to offer a web-based resource for fossil leaf trait data. For this purpose, fossil leaves from various collections were digitized and morphometric traits extracted from leaf outlines. Besides metadata such as accession number, repository, fossil site or taxonomic information (for identified specimens), MORPHYLL offers queries for several morphometric parameters and derived ecophysiological traits (e.g., leaf mass per area). Currently, the database contains data from about 6000 fossil leaves from sites in Central Europe, spanning almost the entire Paleogene and part of the early Neogene. The application potential of the database is demonstrated by conducting some exemplary analyses of leaf traits for the Paleocene, Eocene and Oligocene, with the results indicating changes of mean leaf traits through time. For example, the results show leaf mass per area to peak during the Eocene, which is in accordance with general climate development during the Paleogene.
\end{abstract}

Christopher Traiser. State Museum of Natural History, Rosenstein 1, 70191 Stuttgart, Germany. traiser@smns-bw.de

Anita Roth-Nebelsick. State Museum of Natural History, Rosenstein 1, 70191 Stuttgart, Germany.

Traiser, Christopher, Roth-Nebelsick, Anita, Grein, Michaela, Kovar-Eder, Johanna, Kunzmann, Lutz, Moraweck, Karolin, Lange, Jörg, Kvaček, Jiř́, Neinhuis, Christoph, Folie, Annelise, De Franceschi, Dario, Kroh, Andreas, Prestianni, Cyrille, Poschmann, Markus, and Wuttke, Michael. 2018. MORPHYLL: A database of fossil leaves and their morphological traits. Palaeontologia Electronica 21.1.1T: 1$17 \mathrm{https}: / /$ doi.org/10.26879/773

palaeo-electronica.org/content/2018/2114-database-of-fossil-leaves

Copyright: January 2018 Palaeontology Association.

This is an open access article distributed under the terms of Attribution-NonCommercial-ShareAlike 4.0 International (CC BY-NC-SA 4.0 ), which permits users to copy and redistribute the material in any medium or format, provided it is not used for commercial purposes and the original author and source are credited, with indications if any changes are made.

creativecommons.org/licenses/by-nc-sa/4.0/ 
anita.rothnebelsick@smns-bw.de

Michaela Grein. State Museum of Natural History, Rosenstein 1, 70191 Stuttgart, Germany.

michaela.grein@smns-bw.de; present address: Übersee-Museum Bremen, Bahnhofsplatz 13, 28195

Bremen, Germany.m.grein@uebersee-museum.de

Johanna Kovar-Eder. State Museum of Natural History, Rosenstein 1, 70191 Stuttgart, Germany.

johanna.eder@smns-bw.de

Lutz Kunzmann, Senckenberg Natural History Collections Dresden, Königsbrücker Landstr. 159, 01109

Dresden, Germany. lutz.kunzmann@senckenberg.de

Karolin Moraweck. Senckenberg Natural History Collections Dresden, Königsbrücker Landstr. 159, 01109

Dresden, Germany. karolin.moraweck@senckenberg.de

Jörg Lange. State Museum of Natural History, Rosenstein 1, 70191 Stuttgart, Germany.

joerg.lange@smns-bw.de

Jiří Kvaček. National Museum Prague, Václavské náměsti 68, 11579 Prague 1, Czech Republic.

jiri.kvacek@nm.cz

Christoph Neinhuis. Technische Universität Dresden, Institute for Botany, Zellescher Weg 20b, 01217

Dresden, Germany. christoph.neinhuis@tu-dresden.de

Annelise Folie. Royal Belgian Institute of Natural Sciences, rue Vautier 29, 1000 Brussels, Belgium.

afolie@naturalsciences.be

Dario De Franceschi. CR2P-Sorbonne-Universités, CP38, 57 rue Cuvier, 75231 Paris, France. dario.defranceschi@mnhn.fr

Andreas Kroh. Naturhistorisches Museum Wien, Burgring 7, 1010 Vienna, Austria. andreas.kroh@nhmwien.ac.at

Cyrille Prestianni. Royal Belgian Institute of Natural Sciences, rue Vautier 29, 1000 Brussels, Belgium.

cprestianni@naturalsciences.be

Markus Poschmann. Generaldirektion Kulturelles Erbe RLP, Direktion Landesarchäologie / Erdgeschichte, Niederberger Höhe 1, 56077 Koblenz, Germany. markus.poschmann@gdke.rlp.de

Michael Wuttke. Senckenberg Research Institute, Senckenberganlage 25, 60325 Frankfurt am Main, Germany. michael.wuttke@senckenberg.de

Keywords: leaf database; fossil leaves; leaf traits; leaf morphometry; Paleogene; Central Europe

Submission: 3 April 2017. Acceptance: 6 January 2018

\section{INTRODUCTION}

„... Was soll nun mit den bloßen Abdrücken einzelner Blätter vorweltlicher Pflanzen anzufangen sein?"

(“... Now, what kind of use can we make from bare leaf impressions of primeval plants?")

(Roßmäßler, 1840)

Despite this sceptical comment made by Roßmäßler (1840), fossil leaves represent valuable sources of information for the reconstruction of palaeoenvironments. For example, the findings of Bailey and Sinnott $(1915,1916)$ on negative correlation between the frequency of taxa with toothed leaf margins in a flora and mean annual temperature (MAT) represent an early milestone demonstrating the high value of leaf morphological traits as climate proxy data. Since then, leaf traits have been widely used as proxies for palaeoclimate reconstructions. For example, Leaf Margin Analysis exploits the statistically highly significant negative correlation between frequency of taxa showing toothed leaf margin and mean annual temperature (MAT) (Wolfe and Upchurch 1987; Wilf, 1997; Greenwood et al., 2004; Peppe et al., 2011; Royer et al., 2012). Another approach, the Climate Leaf Analysis Multivariate Program (CLAMP), includes numerous additional correlations between various leaf traits and climate parameters (Wolfe, 1993; Wolfe and Spicer, 1999; Yang et al., 2015). As an example, leaf size (nanophyll, leptophyll, etc.) represents one of the additional traits considered by CLAMP, due to its widely observed correlation with temperature and humidity (Peppe et al., 2011). Over the years, various additional discoveries regarding the impact of climate on leaf morphology 
have been made and evaluated with respect to their suitability as climate proxies. One example is the strong negative correlation of the leaf area occupied by marginal teeth with MAT (Peppe et al., 2011).

Leaf traits are also of increasing interest for studying present-day vegetation and ecosystems. The global leaf economic spectrum (LES), for instance, focuses on the importance of various leaf traits essential for leaf function (Reich et al., 1999; Wright et al., 2005). This approach also includes leaf traits that are not accessible in fossil leaves, such as nitrogen content. A central parameter, however, of the LES, leaf mass per area $\left(\mathrm{LM}_{\mathrm{A}}\right)$, can be assessed indirectly via a morphometric approach developed by Royer et al. (2007). LM shows significant correlations with nitrogen content and leaf life span. The use and value of this indirect approach for palaeoclimate and palaeoecology has been demonstrated by various studies (Royer et al., 2007; Wappler et al., 2009, 2012). Utilizing plant traits in research requires collecting, handling and analysis of particularly large data sets. For extant plants, the initiative "TRY" offers a large database containing traits of recent leaves and other plant organs (Kattge et al., 2011).

Various differences exist between data collection of extant and fossil leaf traits. For example, while the amount and condition of material can be strictly defined for extant leaves, fossil assemblages are often heavily biased by taphonomic filters and preservation processes. Furthermore, the taxonomic affinities of fossil leaves are often ambiguous, unresolved, or their classifications are only referred to higher taxonomic ranks. Various traits are not directly accessible in fossil leaves (for instance, nitrogen content), or are difficult to measure or partially lacking (for instance, higher order venation). Considering the importance of fossil leaf traits in palaeoclimatology and palaeoecology, there is a high demand for available data. Adding new data and techniques to increase the research potential of leaf traits is, therefore, of particular relevance (Blonder and Enquist, 2014; Göldel et al., 2015; Li et al., 2016). Additionally, besides their value in palaeoclimatic and palaeoecologic studies, leaf traits are essential for taxonomy in palaeobotany (Jones et al., 1988; Boulter and Kvaček, 1989; Denk and Dillhoff, 2005; Walther and Kvaček, 2007; Kovar-Eder, 2016). This applies not only to qualitative characters, but also to morphometric parameters (Thiébaut, 2002).

Research approaches based on traits considerably benefit from internet resources making data- bases available for the public (Dalitz and Homeier, 2004; Barclay et al., 2007; Kattge et al., 2011; Marine Species Traits editorial board, 2017). Databases focusing on fossil leaves and their traits, such as the Paleobotany Project (Miller et al., 2005) are rare. Here, we introduce the database "MORPHYLL" containing morphological leaf trait data obtained from fossil angiosperm leaves (http:// www.morphyll.naturkundemuseum-bw.de). The traits comprise directly measured quantitative (= continuous) parameters such as leaf lamina area and perimeter as well as qualitative (= categorical) parameters, such as presence or absence of leaf teeth or lobation. Furthermore, various indirectly obtained traits are included, such as $\mathrm{LM}_{\mathrm{A}}$ or leaf circularity (Huff et al., 2003). The term "leaf shape" will be used here for both qualitative and quantitative numeric leaf traits. In this context, leaf morphometric analysis is understood as the statistical study of leaf shape and their covariation with other, e.g., environmental, variables (Claude, 2008). In contrast to most other existing databases, "MORPHYLL" offers a leaf trait based vegetation analysis tool independent of the taxonomic (phylogenetic) relationship of the leaf assemblages.

The data are based on digital images obtained from the fossil leaf specimens, with subsequent transfer of the leaf outline into GIS shapefile, which is a well-established geospatial vector data format for geographic information systems (GIS). Morphometric data were extracted by spatial SQL-queries applied to GIS shapefiles. Both images and GIS shapefiles are stored in MORPHYLL, together with the extracted morphometric data and various metadata (specimen accession number, fossil site name with stratigraphic position, location of repository/ collection, etc.). Choosing GIS as a tool for morphometric analysis offers various advantages such as flexibility, transparency of image processing, and easy re-analysis for further morphometric parameters. In the following, the structure of MORPHYLL is introduced, together with a brief description of image processing, leaf outline extraction and derived leaf morphometric characters. Furthermore, the analytical potential of MORPHYLL is demonstrated by an exemplary data analysis.

\section{FOSSIL MATERIAL, DATA TYPES AND STORAGE}

\section{Fossil Leaf Collections}

More than 20 collections of fossil leaf floras from eight European museums in five countries are currently included in the database (Table 1). The 
TABLE 1. Summary of specimen included in MORPHYLL until now. ${ }^{1}$ Location number as in Figure 1. ${ }^{2}$ Museums: GDKE: Generaldirektion Kulturelles Erbe Rheinland-Pfalz, Mainz. MfN: Museum für Naturkunde, Berlin. MMG: Museum of Mineralogy and Geology, Dresden. MNHN: Muséum National d'Histoire Naturelle, Paris. NHM: Natural History Museum, Vienna. NMP: National Museum Prague. RBINS: Royal Belgian Institute of Natural Science, Brussels. SMNS: State Museum of Natural History, Stuttgart. ${ }^{3}$ The fossil site "Rauenberg" is also known as "Frauenweiler".

\begin{tabular}{|c|c|c|c|c|c|}
\hline $\begin{array}{l}\text { Location } \\
\text { number }{ }^{1}\end{array}$ & $\begin{array}{l}\text { Number of } \\
\text { specimens }\end{array}$ & $\begin{array}{l}\text { Fossil site } \\
\text { [Country] }\end{array}$ & Age & Epoch & Institution ${ }^{2}$ and City \\
\hline 1 & 54 & Eferding [Austria] & Egerian & Miocene & NHM, Vienna [Austria] \\
\hline $2 a$ & 13 & Linz-Ebelsberg [Austria] & Aquitanian & Miocene & NHM, Vienna [Austria] \\
\hline $2 b$ & 87 & Linz-Pucking [Austria] & Aquitanian & Miocene & NHM, Vienna [Austria] \\
\hline $2 c$ & 42 & Linz-Weikerlsee [Austria] & Aquitanian & Miocene & NHM, Vienna [Austria] \\
\hline 3 & 30 & Borna-Ost/Bockwitz [Germany] & Chattian & Oligocene & MMG, Dresden [Germany] \\
\hline 4 & 417 & Enspel [Germany] & Chattian & Oligocene & GDKE, Mainz [Germany] \\
\hline 5 & 331 & Kleinsaubernitz [Germany] & Chattian & Oligocene & MMG, Dresden [Germany] \\
\hline 6 & 27 & Rott [Germany] & Chattian & Oligocene & RBINS, Brussels [Belgium] \\
\hline 7 & 26 & Witznitz [Germany] & Chattian & Oligocene & MMG, Dresden [Germany] \\
\hline 8 & 217 & Rauenberg ${ }^{3}$ [Germany] & Rupelian & Oligocene & SMNS, Stuttgart [Germany] \\
\hline 9 & 259 & Markvartice u Děčína [Czech Republic] & Rupelian & Oligocene & NMP, Prague [Czech Republic] \\
\hline 10 & 114 & Schleenhain [Germany] & Rupelian & Oligocene & MMG, Dresden [Germany] \\
\hline 11 & 254 & Seifhennersdorf [Germany] & Rupelian & Oligocene & MMG, Dresden [Germany] \\
\hline 12 & 150 & Klausa [Germany] & Priabonian & Eocene & MMG, Dresden [Germany] \\
\hline 13 & 2 & Knau [Germany] & Priabonian & Eocene & MMG, Dresden [Germany] \\
\hline 14 & 1079 & Kučlín [Czech Republic] & Priabonian & Eocene & NMP, Prague [Czech Republic] \\
\hline 15 & 4 & Peres [Germany] & Priabonian & Eocene & MMG, Dresden [Germany] \\
\hline 16 & 32 & Staré Sedlo [Czech Republic] & Priabonian & Eocene & NHM, Vienna [Austria] \\
\hline 17 & 236 & Svatava - Na Pískách [Czech Republic] & Priabonian & Eocene & NMP, Prague [Czech Republic] \\
\hline 18 & 48 & Profen [Germany] & Baronian & Eocene & MMG, Dresden [Germany] \\
\hline 19 & 1090 & Geiseltal [Germany] & Lutetian & Eocene & MfN, Berlin [Germany] \\
\hline $20 a$ & 217 & Sézanne [France] & Thanetian & Paleocene & MNHN, Paris [France] \\
\hline $20 \mathrm{~b}$ & 32 & Sézanne [France] & Thanetian & Paleocene & NHM, Vienna [Austria] \\
\hline $20 c$ & 28 & Sézanne [France] & Thanetian & Paleocene & RBINS, Brussels [Belgium] \\
\hline $21 a$ & 39 & Gelinden [Belgium] & Selandian & Paleocene & NHM, Vienna [Austria] \\
\hline $21 b$ & 488 & Gelinden [Belgium] & Selandian & Paleocene & RBINS, Brussels [Belgium] \\
\hline 22 & 586 & Menat [France] & Selandian & Paleocene & MNHN, Paris [France] \\
\hline
\end{tabular}

fossil leaves, with a stratigraphic range extending from the Paleocene to the Miocene, originate from Central European sites (Figure 1, Table 1). According to Mai (1995), the floras from France, Belgium, Germany and the Czech Republic belong to the Atlantic Boreal Bioprovince, whereas those from Austria are assigned to the Transeuropean Paratethys Bioprovince. Only angiosperm leaves are currently considered in the database. The fossil assemblages are derived from various depositional environments, including fluviatile (e.g., Svatava, Schleenhain, Borna-Ost/Bockwitz), volcano related settings (e.g., Menat, Markvartice, Enspel), as well as allochthonous assemblages from marine envi- ronments (e.g., Rauenberg and the various Austrian sites). Thus, a wide range of habitats and depositional environments are represented in the database.

The number of included fossil leaves per site/ collection varies thus far from a few (e.g., Rott) up to several hundred specimens (e.g., Kučlín, Enspel), depending on the collection size of integrated repositories. Some fossil sites such as Gelinden and Sézanne are represented in the database with different leaf collections stored at different museums (Table 1). Thus, MORPHYLL serves as a database merging dispersed fossil leaf 


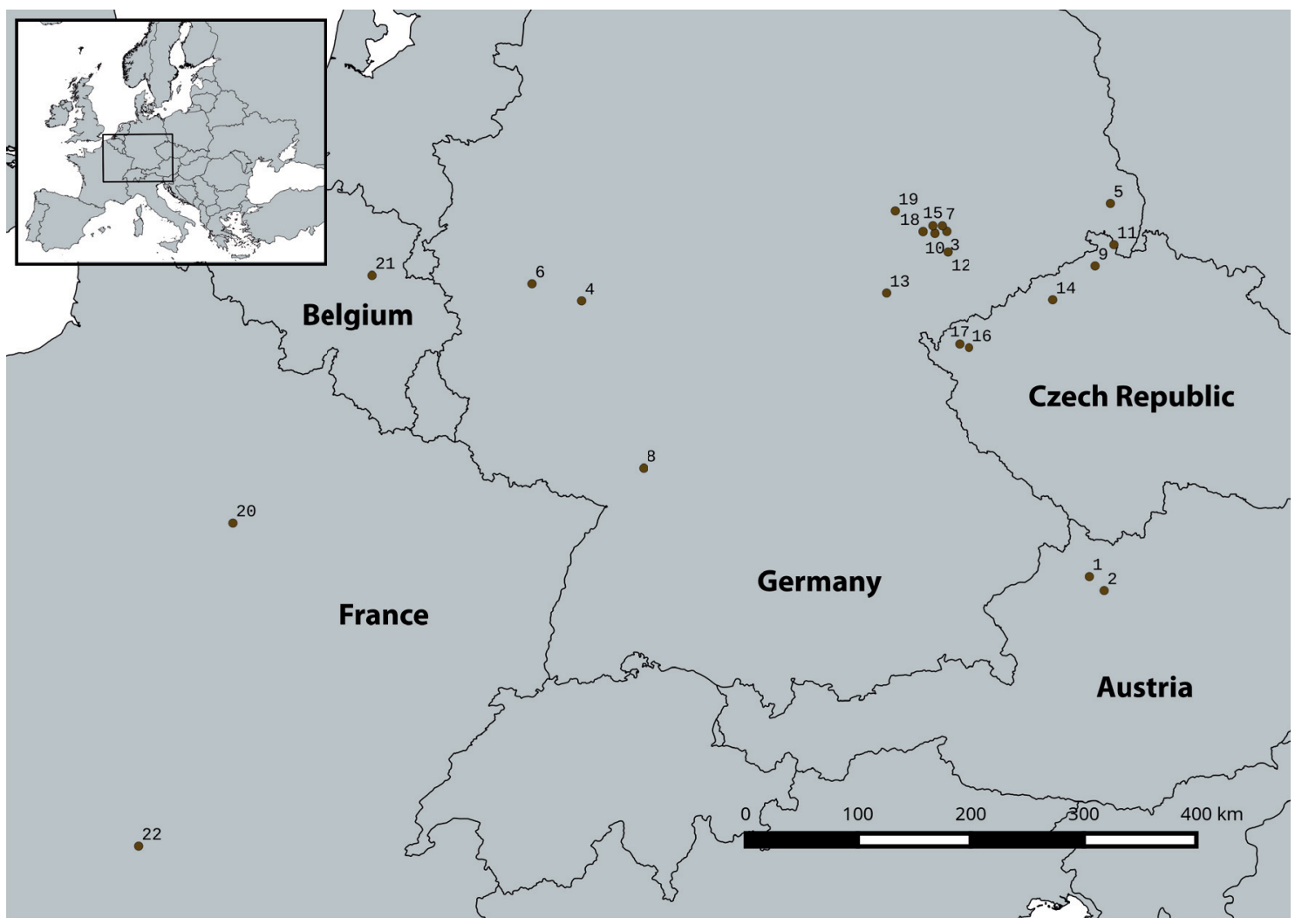

FIGURE 1. Map with fossil sites which are currently included in the database. The numbers indicate the sites, as provided in the leftmost column in Table 1.

collections stored at different European natural history museums.

The taxonomic affiliations of the fossil specimens as provided in the database correspond to information from the inventory catalogues of the museums, from labels or from publications. For some collections, current up-to-date taxonomic determinations are available, such as for the material from the Linz area (Kovar, 1982), Rauenberg (Kovar-Eder, 2016) or for locations in Saxony such as Seifhennersdorf (Walther and Kvaček, 2007). For other collections, however, no recent systematic treatment (revision or monograph) is available. In some cases, the material is completely or partially undetermined, because it represents specimens collected during recent excavations such as Enspel. For some collections, taxonomic identifications date back to the late 1800's, particularly in the case of Paleocene material such as Gelinden (Saporta and Marion, 1873, 1878) or Sézanne (Saporta, 1868) with no recent revisions being available.

The taxonomic status of a collection included in MORPHYLL, therefore, reflects the status quo of taxonomic revision within the respective collec- tions. A complete revision of all leaves included in the database is beyond the scope of this internet resource. Collections which have not been recently taxonomically revised are included because various applications of leaf traits, such as CLAMP, do not rely on taxonomy. Furthermore, considering only recently revised collections would have severely limited the amount of data available. New taxonomic revisions will, however, be considered in the database as soon as they are published. Furthermore, revisions will also be facilitated by information provided by the database of the Muséum National d'Histoire Naturelle, Paris (https://science.mnhn.fr/institution/mnhn/collection/f/item/ search) including images of these collections. The data for the Geiseltal locality represents a special case since the 1090 specimens stored at the Museum für Naturkunde Berlin belong to a single taxon only, Polyspora hallensis RUFFLE (formerly Symplocos hallensis) (Barthel and Rüffle, 1976).

\section{Selection of Specimens}

To improve the overall quality of the data, only those leaves were included in the database, which show a preservation of at least about $60 \%$ of the 
lamina, because reconstruction of complete leaf outlines from very small leaf fragments can induce substantial errors. Leaf fragments, however, may reveal valuable morphological information independent of lamina outline, such as venation type or vein density. Thus, the database also contains some leaf specimens showing only a small subset of all potential leaf traits. Furthermore, leaf specimens showing very poor contrast with the surrounding sediment were excluded since no unequivocal image processing was possible. In cases where both compression and impression of a single specimen are preserved, each is listed in the database as a single entry. The reason for this is that in many cases the compression and the impression differ with respect to identifiable traits. The central entity, i.e., the basic database unit, is represented by a single leaf or leaflet. Thus, fossil leaves consisting of multiple leaflets (compound leaves) are split up into sub-entities - each represented in the database by its own accession number according to the collection catalogue of the hosting institution.

\section{Image Acquisition and Processing}

The data were gathered by conducting several successive steps, starting with: (1) obtaining digital images from the specimens, followed by (2) image processing, (3) leaf outline extraction, (4) calculation of leaf morphometric parameters and (5) data storage. Wherever possible, all compiled data and the database itself were generated by using free open source software (see list below). Images were preferentially produced by scanning the fossil specimen using a high resolution CanoScan-5600F characterised by a high depth of field. If the preservation status of the fossils did not allow for this procedure, depending on the situation onsite, fossil leaves were photographed by using a copystand with an attached Nikon-D5100 digital camera. For photographed leaves, a scale bar was mounted in the focal plane of the leaf lamina to exactly calibrate their size.

The raw images were rotated in order to align the midvein to a vertical position using Adobe Photoshop CS3. After adjusting the contrast, the images were rescaled to match the specimens' actual size (using ImageJ $1.46 a$ ) by referencing to the scale bar. The processed images were stored with $\mathrm{x} / \mathrm{y}$-resolution of 800 pixels per inch (ppi) as Tagged Image File Format (tif) on an image server hosted at the State Museum of Natural History Stuttgart (SMNS).

\section{Leaf Traits and Their Extraction from Images}

In order to calculate leaf morphometric parameters of individual fossils, the leaf outlines were digitised in QGIS (1.8 - 2.8), a free and open source geographic information system (GIS) (http:/ /www.qgis.org/en/site/). For this purpose, the images of fossil leaves were georeferenced to the uppermost part of the leaf petiole if present in the fossil. Thus, for all leaf images, this spot represents the GIS-internal "origin" as this is a homotopic landmark in angiosperm leaves. Both quantitative and qualitative leaf traits are considered in MORPHYLL. Quantitative traits represent continuous data which are mostly based on measurements of morphometric parameters from the GIS shape files. Leaf mass per area $\left(L M_{A}\right)$ is a special case, since it does not represent a morphometric parameter. In the case of fossils, however, this parameter is approximated by determining the lamina area and the maximum width of the uppermost part of the leaf petiole (Royer et al., 2007). Qualitative traits are categorical data, describing shape characteristics of leaves, such as toothed or untoothed margins (Ellis et al., 2009). The traits and their extraction from the images are briefly introduced and discussed in the following section.

\section{Quantitative Traits}

Leaf outline. After georeferencing leaf images, the leaf outlines were digitised by hand in order to generate shapefiles. Owing to the fact that many fossil leaves are fragmented and thus some parts of the laminae are missing, two versions of outlines were generated for each leaf: (1) a minimum outline representing unequivocally parts of the fragmented lamina (frag) and (2) a maximum outline representing the complete replenished lamina (repl), based on a subjective interpretation of the lamina shape of the respective specimen (Figure 2).

Spatial Structured Query Language (SQL) served to calculate quantitative leaf morphometric parameters such as leaf area or outline length. For this purpose, the shapefiles of leaf outlines were imported to an object-relational PostgreSQL-database (9.1.16) with PostGIS (2.0.4) extension adding support for spatial queries to be run in SQL. A set of quantitative morphometric parameters is then extracted from replenished leaf outlines. In order to provide information on the amount of lamina reconstruction for each specimen, the area index $(I A)$ is also included in the database. The area index is calculated as the ratio of lamina area of fragmented and replenished leaf outlines. It is, therefore, a measure for the proportion of the pre- 


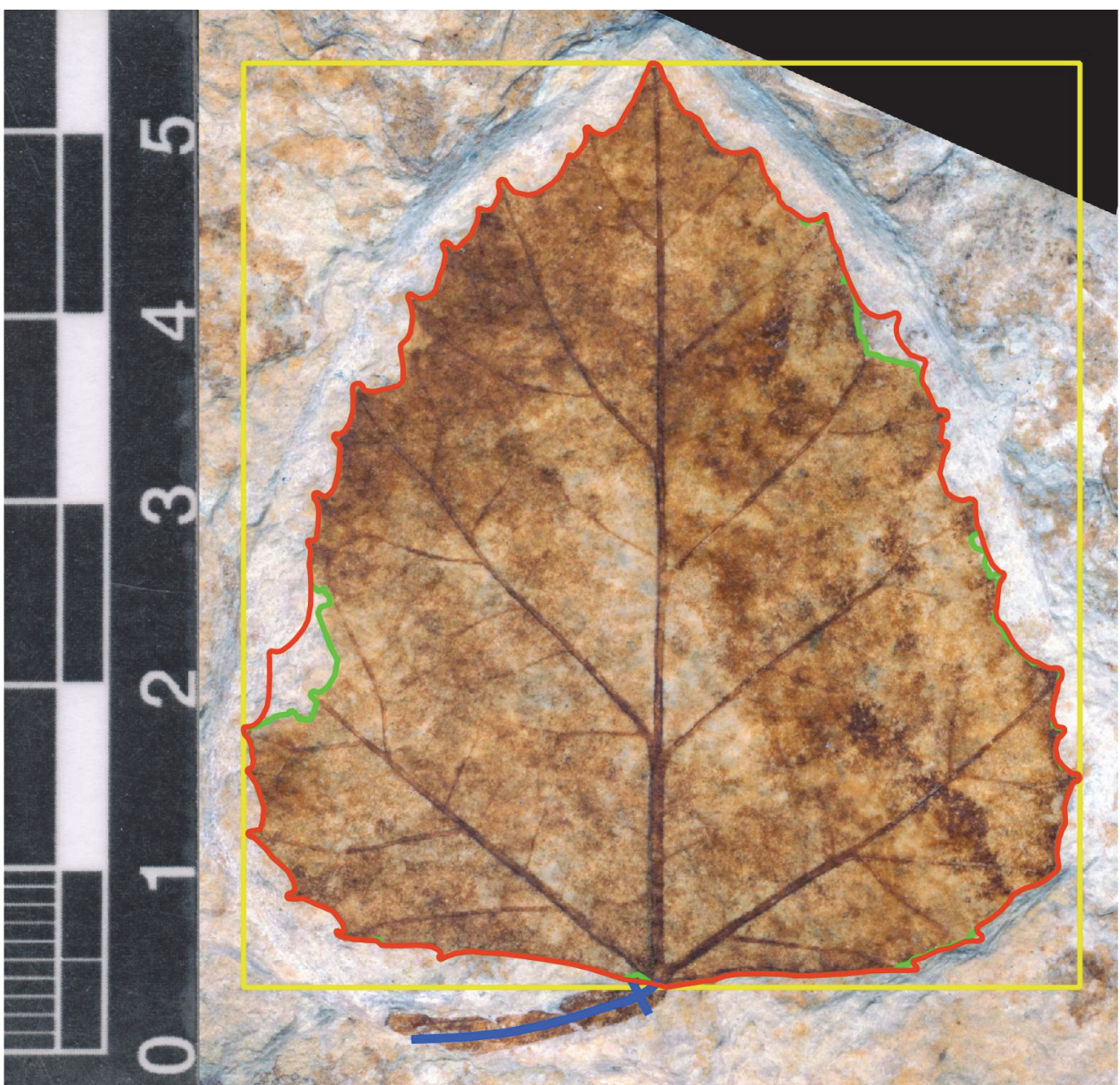

FIGURE 2. Example for the process of producing shapefiles from fossil leaf images. Green line: outline of original fossil. Red line: outline of replenished leaf. The red line partially covers the green line. Blue lines: petiole length and petiole width at the most apical point of the petiole. Yellow rectangle: bounding box encasing the specimen. Craspedodromophyllum betuloides Kvaček and Teodoridis, 2011 (NMP_G11231, Prague).

served parts of the lamina with respect to the reconstructed lamina. For example, a value of 0.9 means that $90 \%$ of the original lamina is preserved while $10 \%$ of the lamina area is reconstructed.

Lamina area and perimeter. Lamina area $(A)$ and perimeter $(P)$ are calculated directly from the $x / y-$ coordinates of the leaf lamina outlines. These leaf traits and all other "leaf morphometric" parameters such as leaf length and width consider only the lamina without the petiole.

Lamina length, width and length/width ratio. The calculations of lamina length $(L)$ and width $(W)$ are based on the bounding box of the leaf outline. The bounding box is a minimum bounding rectangle enclosing the outline paraxial to image margins defining the $x$ - (width) and $y$ - (length) extent of the leaf (Figure 2). The lamina length/width ratio (LW) corresponding to the aspect ratio is derived from these values (Ellis et al., 2009). Leaves with a high LW show an elongated shape.

Position of lamina centroid. The position of lamina centroid $\left(C_{e n}\right)$ is calculated as the distance (D) of centre of gravity from the lamina base with respect to the total leaf length $(L)$ in percent (Barthel and Rüffle, 1976). For example, a value of $50 \%$ corresponds to a centre of gravity exactly in the middle length of the lamina, whereas a value of $60 \%$ indicates an apical shift of the centre of gravity. The position of the centre of gravity reflects leaf shape: leaves with a low value tend to show an ovate shape, whereas leaves with a high value tend to show an obovate shape.

$$
C_{e n}=D * 100 / L \epsilon[0,100]
$$

Lamina circularity. Lamina circularity $\left(C_{i r}\right)$ is calculated as the quotient of lamina area $(A)$ and 
perimeter squared $\left(\mathrm{P}^{2}\right)$, in relation to a unit circle (Huff et al., 2003). Thus, a value of 1 corresponds to a perfect circle, whereas a value of 0 represents a linear structure. Therefore, $\mathrm{C}_{\text {ir }}$ principally shows the "roundness" of a leaf. In leaves with ragged or toothed margins, however, $\mathrm{C}_{\text {ir }}$ may be biased.

$$
C_{i r}=4 \pi{ }^{*} A / P^{2} \epsilon[0,1]
$$

Petiole length and width. A line string (a onedimensional shapefile in GIS) from which the petiole length $\left(P_{I}\right)$ was calculated (Figure 2) served to redraw the course of the petiole if the complete petiole as well as fragmented parts are observed. The petiole width $\left(P_{w}\right)$ was recorded by a line string drawn perpendicular to the line string of petiole length close to the point of attachment to the lamina (Royer et al., 2007). The petiole width is required to calculate leaf mass per area.

Leaf mass per area. Leaf mass per area $\left(L M_{A}\right)$ is calculated according to Royer et al. (2007), based on relation of petiole width $\left(\mathrm{P}_{\mathrm{w}}\right)$ and lamina area (A).

$$
\log \left(L M_{A}\right)=a+b{ }^{*} \log \left(P_{w}{ }^{2} / A\right)
$$

with constants $a=3.070$ and $b=0.382$ (Royer et al., 2007).

$\mathrm{LM}_{\mathrm{A}}$ is an important parameter in leaf economics, being for example positively correlated with leaf life span (Wright et al., 2004).

\section{Qualitative Leaf Traits}

In addition to quantitative morphometric parameters, qualitative traits of leaf shape and venation were determined for each specimen including lobation, leaf margin type, primary and secondary vein framework, and leaf size class as determined following the Manual of Leaf Architecture (Ellis et al., 2009) (Table 2). These leaf traits are recorded at the highest hierarchical level character states. For example, untoothed/toothed represents the highest hierarchical level for leaf margin type, while dentate/serrate/crenate is the next lower hierarchical level for toothed leaf margins. Lower hierarchical levels will be subsequently added to the database. Additionally, the presence/ absence of the petiole was recorded for each leaf.

\section{DATA ACCESS AND QUERY}

All data of MORPHYLL are stored and managed by a PostgreSQL-server hosted at the State Museum of Natural History Stuttgart (SMNS). Five different data types are stored in the database (Table 2): (1) collection metadata of the specimen, such as accession number, (2) taxonomic data, if available, (3) qualitative data, (4) quantitative data and (5) the geometric data in the form of extracted shapefiles. In addition, leaf images from all specimens are also stored in MORPYHLL.

All data types including geometries of shapefiles are provided by the PostgreSQL-server for clients such as QGIS or the statistic software

TABLE 2. List of parameters stored in MORPHYLL. Parameters marked with an asterisk are included in the query mask (partially upon registration). Morphological traits used as defined by Ellis et al. (2009). Parameter without an

\begin{tabular}{|c|c|c|c|c|}
\hline Meta data & $\begin{array}{l}\text { Taxonomic } \\
\text { data }\end{array}$ & Qualitative data & Quantitative data & Geometry data (Shapefiles) \\
\hline $\begin{array}{l}\text { Specimen accession } \\
\text { number }^{\star}\end{array}$ & $\begin{array}{l}\text { Taxon } \\
\text { (species) }^{*}\end{array}$ & Leaf margin type* & Lamina area $\left[\mathrm{mm}^{2}\right]^{\star}$ & Lamina outline (polygon) \\
\hline Name of institution* & Genus* $^{*}$ & Leaf lobation type* & Lamina perimeter [mm] & Petiole length (linestring) \\
\hline Name of fossil site ${ }^{*}$ & Family* & Leaf shape type & Lamina length $[\mathrm{mm}]^{*}$ & Petiole width (linestring) \\
\hline Country of fossil site* & Order* & Leaf size class* & Lamina width $[\mathrm{mm}]^{*}$ & Primary veins (multilinestrings) \\
\hline Stratigraphic age* & & $\begin{array}{l}\text { Primary vein } \\
\text { architecture type* }\end{array}$ & $\begin{array}{l}\text { Lamina length-to-width } \\
\text { ratio }[-]^{*}\end{array}$ & Secondary veins (multilinestrings) \\
\hline \multirow[t]{6}{*}{ Stratigraphic epoch* } & & $\begin{array}{l}\text { Secondary vein } \\
\text { architecture type* }\end{array}$ & Lamina circularity $[-]$ & Tertiary veins (multilinestrings) \\
\hline & & Petiole preservation* & Lamina centroid [\%] & \\
\hline & & & Area index $[-]^{*}$ & \\
\hline & & & Petiole length $[\mathrm{mm}]^{*}$ & \\
\hline & & & Petiole width $[\mathrm{mm}]^{*}$ & \\
\hline & & & Leaf mass per area $\left[\mathrm{g} / \mathrm{m}^{2}\right]$ & \\
\hline
\end{tabular}
asterisk can be obtained directly from the curator (see main text). 
environment $R$ ( $R$ Development Core Team, 2015) by defined database interfaces. Leaf images as well as the shapefiles of leaf outlines or leaf venation can immediately be visualised and edited in GIS. For statistical analyses, user-defined data subsets can easily be retrieved from an R-environment by using SQL-queries. The data portal of the MORPHYLL-project is available for the public at http://www.morphyll.naturkundemuseum-bw.de (Appendix 1).

The website offers a brief overview of the database content, incorporated fossil leaf collections and methods. A summary of the database content is given at the MORPHYLL-data portal in the menu "Database-Synopsis". The synopsis shows a compilation of stored data with regard to fossil locality names, the number of fossil specimen, stratigraphic position and institutions hosting the collections. The search form of the MORPHYLL data portal (menu: "Database-Query") allows combining queries for all kinds of metadata, taxonomic data, qualitative and quantitative data. All searchable parameters are summarized in Table 2. The results are compiled according to the query in a generated table. The summary table of queries provides the collection metadata of the fossil specimen, qualitative and quantitative data depending on selection made in the query form. Currently, metadata and taxonomic data are available for the public whereas qualitative, quantitative and spatial data are restricted to registered users. To register and to get full access to the complete set of data including morphometry and high resolution images, please contact the curator of fossil plants at SMNS (anita.rothnebelsick@smnsbw.de).

\section{RESULTS AND DISCUSSION}

\section{Data Content}

At present, the database contains about 6000 fossil specimens from 24 localities from five countries (Table 1, Figure 1). Since, in the case of compound leaves, each leaflet is treated as an individual entry, the number of records provided after a query does not necessarily reflect the real number of fossil specimens in the collection. The stratigraphic interval covered by the database encompasses nearly the complete Paleogene ranging from middle Paleocene (Selandian) up to the lowermost Miocene (Aquitanian). Currently, however, the lower and middle Eocene material is quite limited with respect to number of sites (Geiseltal area) and taxa. It is hoped to fill this gap in the database soon. Furthermore, it is planned to expand the database to include Miocene and Pliocene material. For various sites, the material is distributed across different museums, such as the fossil floras of Gelinden (Selandian) and Sézanne (Thanetian) which are housed in the museums of Brussels, Paris and Vienna (Table 1). The database allows for statistical analysis of qualitative and quantitative leaf traits, as well as of their combinations. All data types provided by the database MORPHYLL can be transferred to higher level geoscientific data portals, e.g., GeoCASe (Geosciences Collection Access Service).

The database MORPHYLL offers the possibility of retrieval of fossil leaf traits in combination with traditional collection metadata such as taxonomic, stratigraphic or geographic data. This allows a specific search for fossil leaf traits and, therefore, ecomorphological aspects independent of taxonomic determination. From the point of taxonomic determination, approximately $67 \%$ (about 3800 specimens) of leaves in the database have taxonomic affiliations. The proportion of identified specimens in the database decreases further since the collection of Geiseltal (1100 specimens) stored at the Museum für Naturkunde Berlin thus far comprises only a single taxon, namely Polyspora hallensis (Theaceae). This demonstrates that the potential information provided by leaf assemblages may decrease when only taxonomically well-classified collections are taken into consideration. Leaf traits as compiled in the database offer access to morphometric information independent of taxonomic status of the leaves.

In the following sections, some general analyses of trait variation through time (Paleocene, Eocene and Oligocene) will be shown to give a first impression of the current analytic potential of the database. All data were used with the exception of the Geiseltal site.

\section{Leaf Margin}

To demonstrate the potential for analysis of qualitative data, the distribution of leaf margin types was chosen as a first example. The leaf margin, toothed vs. untoothed, is one of the most widely applied plant traits in palaeobotany due to its extensive use as an environmental proxy for MAT (Bailey and Sinnott, 1915, 1916; Wilf, 1997; Greenwood et al., 2004; Su et al., 2010; Hinojosa et al., 2011; Royer et al., 2012). Altogether, approximately 3200 fossil specimens are currently available for determination of leaf margin characters. Figure 3 shows the frequency of toothed/untoothed 


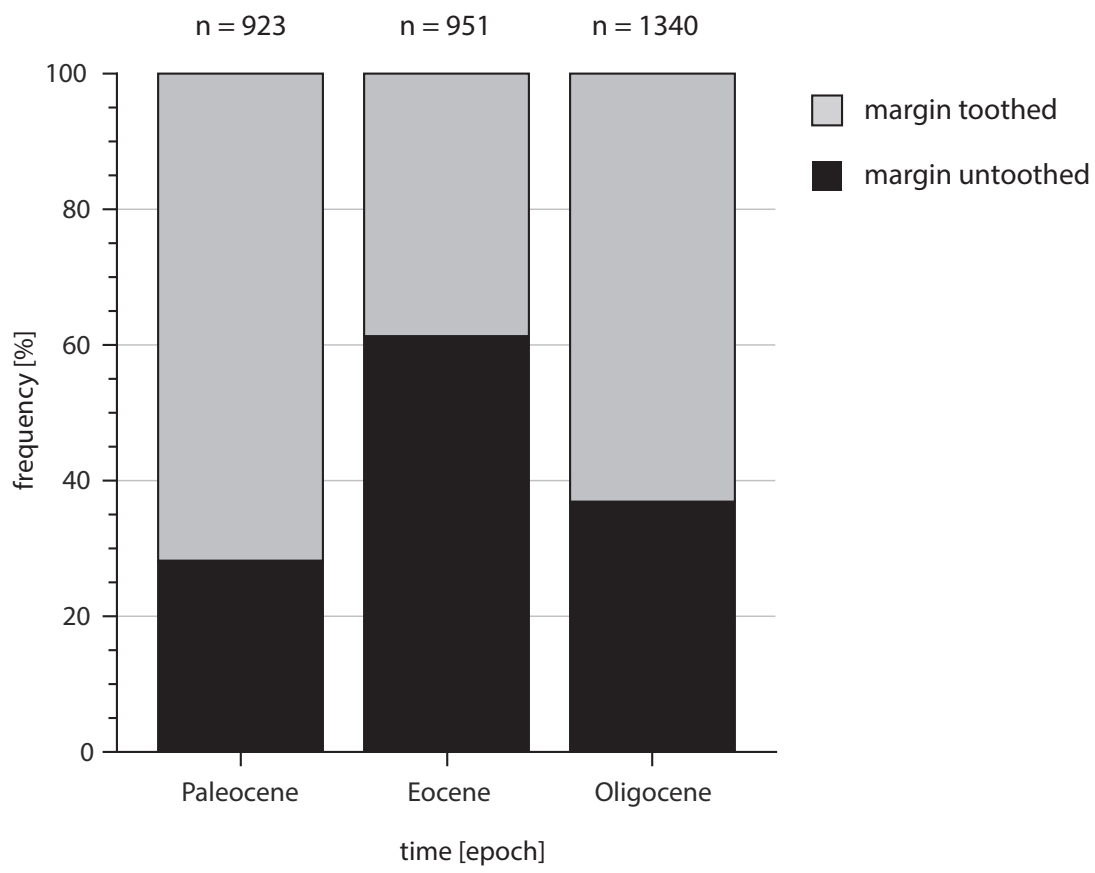

FIGURE 3. Frequency of toothed and untoothed leaf margins for the Paleocene, Eocene and Oligocene, obtained for 3214 specimens in MORPHYLL. Significance level (Pearson Chi-Square) $<0.001$.

leaf margin for leaves from the Paleocene, Eocene and Oligocene. Although there are different numbers of fossils per epoch, the amount of data available for recognizing leaf margin types are quite similar. The data clearly indicate a statistically significant higher proportion of untoothed margins during the Eocene (about $60 \%$ ) compared to that of the Paleocene and Oligocene floras.

This result is consistent with the general interpretation of warmer and equable climate conditions during the Eocene. For a more detailed analysis, additional aspects, such as habitat type or taphonomic effects as well as phylogenetic influence have to be taken into account (Ferguson, 1985; Burnham et al., 2001; Ferguson, 2005; Doyle, 2007; Little et al., 2010; Astorga et al., 2016). Even on this coarse scale with lumped data for each epoch, the intrinsic signal of leaf margin type is still obvious. The available data reveal a remarkably high proportion of toothed leaves in the Paleocene and Oligocene, compared to the Eocene. With respect to the Paleocene, only a few hints exist concerning the leaf margin composition of the vegetation, mainly due to the lack of well-studied Paleocene macro-floras in Central Europe. According to Mai (1995), $15 \%$ of a lower Paleocene flora (Eisleben, Germany, not included in MORPHYLL) have untoothed leaf margins whereas Mouton (1975) notes $37 \%$ untoothed $(41 \%$ toothed, the rest classified as "other") leaves for the Thanetian flora of Sézanne (which is not completely included in this study due to still unclassified leaf traits).

\section{Lamina Area}

The number of quantitative data is lower than qualitative data, because only leaves which showed a low degree of fragmentation were selected for quantitative analyses (area index > 0.75 ), whereas all leaves allowing for identification of qualitative traits were used for obtaining qualitative data. Currently, most morphometric data originate from Oligocene material (Figure 4.1). The Eocene material appears to contain somewhat smaller leaves, which is statistically corroborated for the Eocene and Oligocene data $(p<0.001$, Kruskal-Wallis, and Conover-Inman pairwise comparison).

\section{Lamina Circularity}

Leaf circularity is shown in Figure 4.2. For the Paleocene and Oligocene, the data shows lower values, whereas the Eocene leaves appear to reveal a slight trend towards rounder leaves. The observed trends are statistically significant $(p<$ 0.001 , Kruskal-Wallis, and Conover-Inman pairwise comparison). Circularity is, however, affected by the margin type, because the presence of teeth can bias this parameter; a perimeter based on a "non-smooth" outline decreases circularity of an object. Furthermore, lobed leaves contribute to 

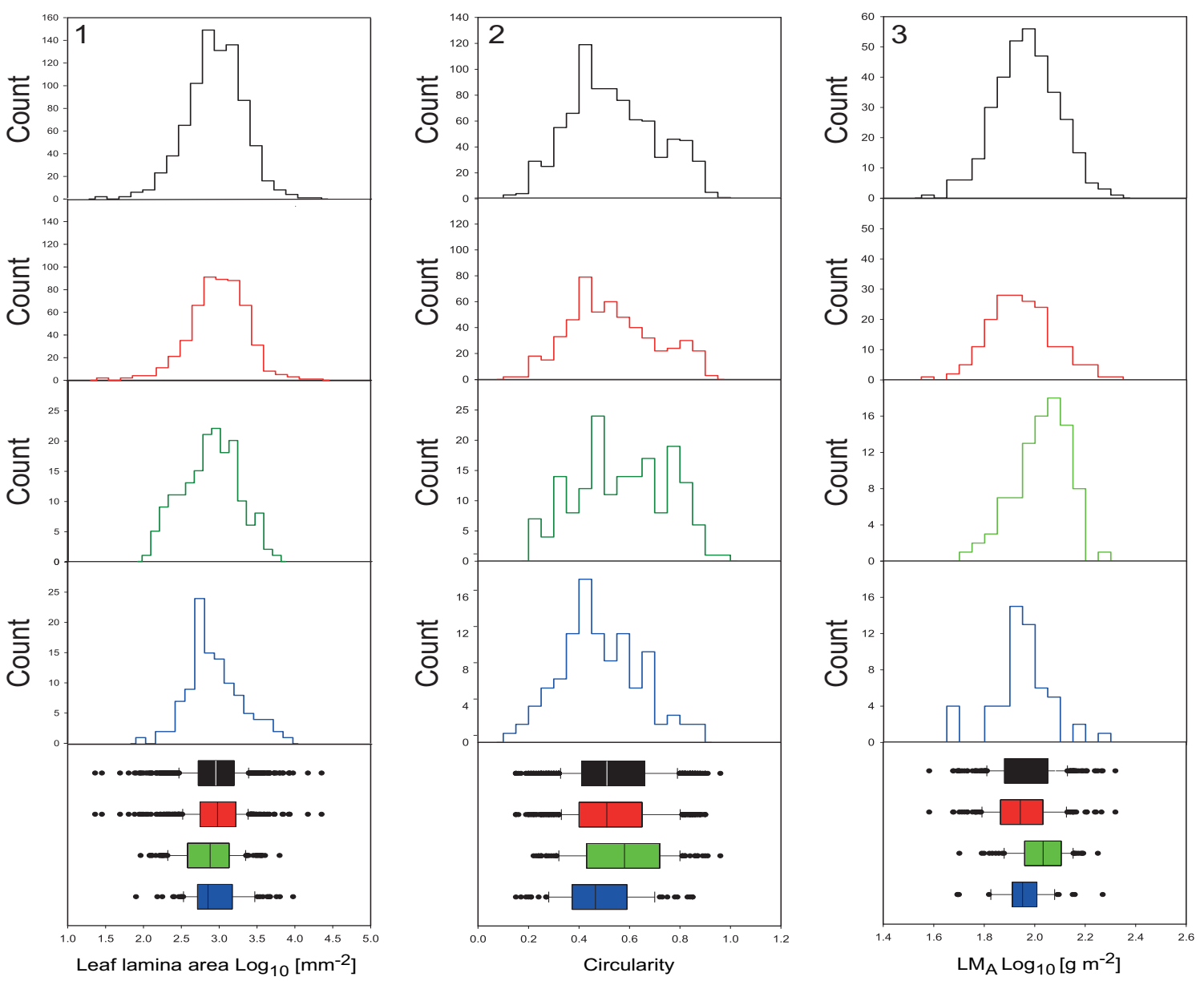

FIGURE 4. Data distribution of leaf lamina area (1), leaf circularity (2) and leaf mass per area $\left(\mathrm{LM}_{\mathrm{A}}\right)$ (3) for the Paleocene (blue graphs and box plots), Eocene (green graphs and box plots), Oligocene (red graphs and box plots) and all data (black graphs and box plots). The box plots span the $50 \%$ interquartile. The lines within the boxes indicate the median values. The "whiskers" mark the highest and lowest values. Outliers are drawn as filled circles.

lower circularity values of the Paleocene and Oligocene (lobed leaves are almost absent during the Eocene).

\section{Leaf Mass per Area}

Another example for quantitative leaf trait analysis is $L M_{A}$ from the Paleocene to the Oligocene (Figure 4.3). Leaf mass per area is positively correlated with leaf life span and thus serves as an indicator for evergreen or deciduous vegetation (Wright et al., 2005). As explained above, $\mathrm{LM}_{\mathrm{A}}$ can be approximated for fossil plants by biomechanical considerations, based on lamina area and petiole width (Royer et al., 2007). Unfortunately, the petioles of fossil leaves are often absent with only about $15 \%$ of all specimens stored in MORPHYLL, possessing petioles. Sample sizes to reconstruct $\mathrm{LM}_{\mathrm{A}}$ for fossil material are therefore usually quite small. Additionally, only specimens with IA $>0.75$ were included in this analysis. The low frequency of suitable specimens from a collection becomes obvious when comparing the count numbers for $\mathrm{LM}_{\mathrm{A}}$ (Figure 4.3) with lamina area (Figure 4.1) and circularity (Figure 4.2).

The $L M_{A}$ data set reveals a statistically significant trend. The highest value for $L_{A}$ is shown by the Eocene data set, whereas the Paleocene and Oligocene show lower values. The observed trend is statistically significant $(p<0.001$, Kruskal-Wallis, and Conover-Inman pairwise comparison). This result indicates a shift towards longer leaf life span and, therefore, towards a "slow return" strategy for the Eocene vegetation, compared to that of the Paleocene and Oligocene. Wappler et al. (2012) published means of leaf mass with values of $123 \mathrm{~g} /$ $\mathrm{m}^{2}\left(2.09 \log _{10} \mathrm{~g} / \mathrm{m}^{2}\right)$ for Messel and $111 \mathrm{~g} / \mathrm{m}^{2}$ for 

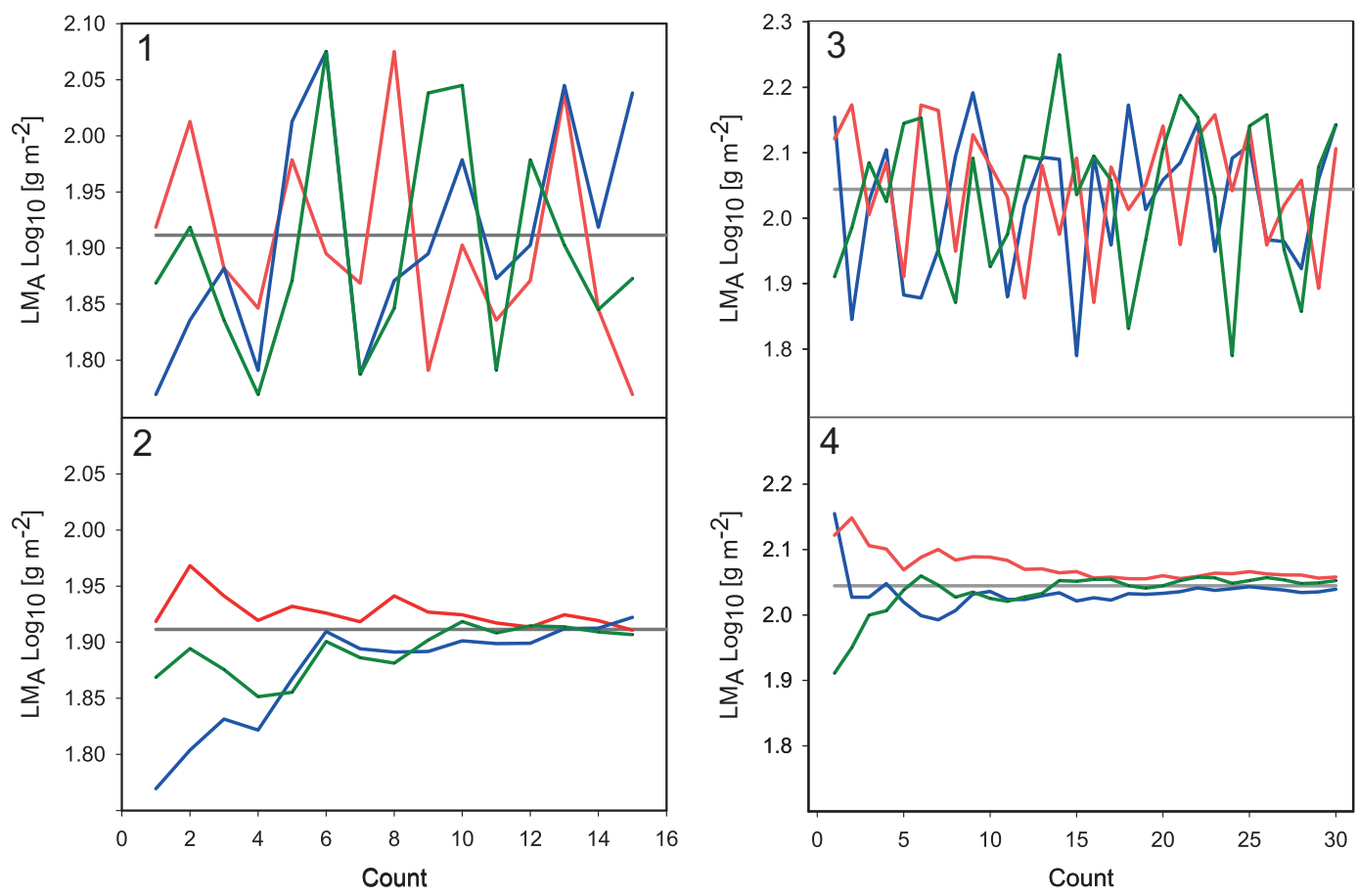

FIGURE 5. Random sampling analysis for $L_{A}$, for evaluation of the number of data required to arrive at a statistically stable signal. (1) Three independent rounds (blue, green and red) of drawing 15 random samples from specimens of one taxon (Platanus neptuni), site Rauenberg (Oligocene). The grey horizontal line represents the mean value for all specimens of $P$. neptuni from Rauenberg. The graphs show the $L_{A}$ value of each random sample. (2) The course of the mean value of $\mathrm{LM}_{\mathrm{A}}$, calculated after each drawing cycle. (3) Three independent rounds (blue, green and red) of drawing 30 random samples from all specimens from the site Kučlín (Eocene). The grey horizontal line represents the mean value for all specimens. The graphs show the $\mathrm{LM}_{\mathrm{A}}$ value of each random sample. (4) The course of the mean value of $L M_{A}$, calculated after each drawing cycle.

Eckfeld $\left(2.05 \log _{10} \mathrm{~g} / \mathrm{m}^{2}\right.$ ) (both of Middle Eocene age). For the Eocene data set currently stored in MORPHYLL, the mean value for $L_{A}$ amounts to $2.03 \log _{10} \mathrm{~g} / \mathrm{m}^{2}$. In contrast, the leaves of the Paleocene (1.95 $\left.\log _{10} \mathrm{~g} / \mathrm{m}^{2}\right)$ and Oligocene (1.94 $\log _{10} \mathrm{~g} / \mathrm{m}^{2}$ ) are characterised by a trend towards lower $\mathrm{LM}_{\mathrm{A}}$ and therefore towards a "fast return" strategy with lower leaf life span. For comparison, according to Royer et al. (2007), leaves with a $\mathrm{LM}_{\mathrm{A}}$ $<87 \mathrm{~g} / \mathrm{m}^{2}\left(1.94 \log _{10} \mathrm{~g} / \mathrm{m}^{2}\right)$ are probably deciduous.

\section{Quality of Morphometric Signals}

The different number of leaves available for the various epochs, ages, sites or parameters raises the question of how many leaves are required to obtain a meaningful signal. To explore the dependence of the signal from the number of leaves for the MORPHYLL data, a study was carried out for $\mathrm{LM}_{\mathrm{A}}$ at two sites, Kučlín (Eocene) and Rauenberg (Oligocene). $\mathrm{LM}_{\mathrm{A}}$ was selected, because the number of suitable leaves is usually low mainly due to the lack of a petiole, rendering $\mathrm{LM}_{\mathrm{A}}$ a statistically problematic parameter. For Kučlín, the entire data set with all specimens was included, whereas for Rauenberg, only one taxon, Platanus neptuni, was considered. Kučlín was selected for the analysis of all available specimens, because a large number of $L M_{A}$ data for the entire data set exists for this site. Rauenberg and $P$. neptuni were selected, as a comparatively large number of $L_{A}$ data of well-classified specimens of $P$. neptuni were present. Using available routines in the open source software R, version 3.1.2. (www.rproject.org/), random samples (specimens) were drawn from these $L M_{A}$ data sets without replacement. After each sampling cycle, the mean value of $L M_{A}$ was calculated. The random sampling was finished when the results started to converge. Three independent rounds were performed for each data set.

The results are shown in Figure 5. In the case of Platanus neptuni, and thus for a single taxon, 
about 10 leaves appear to be sufficient to achieve an acceptable approximation of the mean value for $\mathrm{LM}_{\mathrm{A}}$ (Figure 5.1-2). For an entire leaf flora, showing a much higher variation of leaf shape and size, about 15 leaves are necessary (Figure 5.3-4), as demonstrated by the Kučlín site. Therefore, the results shown by the plots in Figure 4 for lamina area, circularity and $\mathrm{LM}_{\mathrm{A}}$ should be statistically stable. It should be emphasized, however, that this refers to the statistical signal for the available material, not necessarily for the original vegetation since a fossil leaf flora is not expected to fully represent the original floral composition.

\section{CONCLUSIONS}

The database MORPHYLL allows for query and statistical analyses of various morphometric traits. Besides the potential to compare fossil leaf assemblages based on their trait combinations, the database can also be used for species-specific analyses. Due to the varying ecological background of the considered sites, studies concerning the effects of, among others, habitat types are also possible. Currently, the database includes Paleogene leaf assemblages, but will be expanded to increase the number of specimens and sites, as well as to extend the stratigraphic range covered.

\section{ACKNOWLEDGEMENTS}

This project was supported by the German Research Foundation (DFG) by a grant to A. R.-N. and J. K.-E. (RO 3250/21-1) (Program "Scientific Library Services and Information Systems (LIS)"), and partially by the Volkswagen Foundation to a grant to A. R.-N., J. K.-E., L. K., C. N. and J. K. (Program"Research in Museums). (Program "Research in Museums"). Furthermore, within this study, data collection at the Muséum National d'Histoire Naturelle Paris in 2014 was supported by SYNTHESYS (FR-TAF-3414), by a grant to C.T. We thank M. Kamenz, J. Wypich (SMNS, Stuttgart, Germany), C. Puffert, C. Hiller (MfN, Berlin, Germany) and M. Wettlaufer (GDKE, Mainz, Germany) for administrative and technical support, and $B$. Mohr and S. Schultka (MfN, Berlin, Germany) for allowing their collection to be included in MORPHYLL. J. Nebelsick, University of Tübingen, is acknowledged for critically reading the English text. We also thank three anonymous reviewers for their constructive comments, which greatly helped to improve the manuscript.

\section{REFERENCES}

Astorga, G.A., Jordan, G.J., and Brodribb, T. 2016. Towards understanding the fossil record better: Insights from recently deposited plant macrofossils in a sclerophyll-dominated subalpine environment. Review of Palaeobotany and Palynology 233:1-11. https://doi.org/ 10.1016/j.revpalbo.2016.06.004

Bailey, I.W. and Sinnott, E.W. 1915. A botanical index of Cretaceous and Tertiary climates. Science 41:831-834.

Bailey, I.W. and Sinnott, E.W. 1916. The climatic distribution of certain types of Angiosperm leaves. American Journal of Botany, 3:24-39.

Barclay, R., McElwain, J., Diloksumpun, S., and Sageman, B. 2007. The cuticle database: developing an interactive tool for taxonomic and paleoenvironmental study of the fossil cuticle record. Courier Forschungsinsitut Senckenberg, 258:39-55.

Barthel, M. and Rüffle, L. 1976. Ein Massenvorkommen von Symplocaceenblättern als Beispiel einer Variationsstatistik, 291-305. In Paläontologische Abhandlungen. Zentrales Geologisches Institut, Berlin, DDR.

Blonder, B. and Enquist, B.J. 2014. Inferring climate from angiosperm leaf venation networks. New Phytologist, 204:116-126. https://doi.org/10.1111/nph.12780

Boulter, M. and Kvaček, Z. 1989. The Palaeocene Flora of the Isle of Mull. Special Papers in Palaeontology, The Palaeontological Association London 42:149.

Burnham, R.J., Pitman, N.C.A., Johnson, K. R., and Wilf, P. 2001. Habitat-related error in estimating temperatures from leaf margins in a humid tropical forest. American Journal of Botany, 88:1096-1102.

Claude, J. 2008. Morphometrics with R. Springer, New York.

Dalitz, H. and Homeier, J. 2004. Visual Plants-Image based tool for plant diversity research. Lyonia, 6:47-59. 
Denk, T. and Dillhoff, R.M. 2005. Ulmus leaves and fruits from the Early-Middle Eocene of northwestern North America: systematics and implications for character evolution within Ulmaceae. Canadian Journal of Botany, 83:1663-1681. https://doi.org/10.1139/b05-122

Doyle, J.A. 2007. Systematic value and evolution of leaf architecture across the angiosperms in light of molecular phylogenetic analyses. Courier Forschungsinstitut Senckenberg, 258:2137.

Ellis, B., Daly, D.C., Hickey, L.J., Johnson, K., Mitchell, J.D., Wilf, P., and Wing, S.L. 2009. Manual of Leaf Architecture. The New York Botanical Garden Press, Ithaca.

Ferguson, D.K. 1985. The origin of leaf-assemblages - new light on an old problem. Review of Palaeobotany and Palynology, 46:117-188. https://doi.org/10.1016/0034-6667(85)90041-7

Ferguson, D.K. 2005. Plant taphonomy: Ruminations on the past, the present, and the future. PALAIOS, 20:418-428. https://doi.org/10.2110/palo.2005.P05-25p

Göldel, B., Kissling, W.D., and Svenning, J.-C. 2015. Geographical variation and environmental correlates of functional trait distributions in palms (Arecaceae) across the New World. Botanical Journal of the Linnean Society, 179:602-617. https://doi.org/10.1111/boj.12349

Greenwood, D.R., Wilf, P., Wing, S.L., and Christophel D.C. 2004. Paleotemperature estimation using leaf-margin analysis: Is Australia different? PALAIOS, 19:129-142. https://doi.org/ 10.1669/0883-1351(2004)019<0129:PEULAI>2.0.CO;2

Hinojosa, L.F., Pérez, F., Gaxiola, A., and Sandoval, I. 2011. Historical and phylogenetic constraints on the incidence of entire leaf margins: insights from a new South American model. Global Ecology and Biogeography, 20:380-390. https://doi.org/10.1111/j.14668238.2010.00595.x

Huff, P.M., Wilf, P., and Azumah, E.J. 2003. Digital Future for paleoclimate estimation from fossil leaves? Preliminary results. PALAIOS, 18:266-274. https://doi.org/10.1669/08831351(2003)018<0266:DFFPEF>2.0.CO;2

Jones, J.H., Manchester, S.R., and Dilcher, D.L. 1988. Dryophyllum Debey ex Saporta, Juglandaceous not Fagaceous. Review of Palaeobotany and Palynology, 56: 205-211. https:/ /doi.org/10.1016/0034-6667(88)90059-0

Kattge, J., Díaz, S., Lavorel, S., Prentice, I.C., Leadley, P., Bönisch, G., Garnier, E., Westoby, M., Reich, P.B., Wright, I.J., Cornelissen, J.H.C., Violle, C., Harrison, S.P., Van Bodegom, P.M., Reichstein, M., Enquist, B.J., Soudzilovskaia, N.A., Ackerly, D.D., Anand, M., Atkin, O., Bahn, M., Baker, T.R., Baldocchi, D., Bekker, R., Blanco, C.C., Blonder, B., Bond, W.J., Bradstock, R., Bunker, D.E., Casanoves, F., Cavender-Bares, J., Chambers, J.Q., Chapin III, F.S., Chave, J., Coomes, D., Cornwell, W.K., Craine, J.M., Dobrin, B.H., Duarte, L., Durka, W., Elser, J., Esser, G., Estiarte, M., Fagan, W.F., Fang, J., Fernández-Méndez, F., Fidelis, A., Finegan, B., Flores, O., Ford, H., Frank, D., Freschet, G.T., Fyllas, N.M., Gallagher, R.V., Green, W.A., Gutierrez, A.G., Hickler, T., Higgins, S.I., Hodgson, J.G., Jalili, A., Jansen, S., Joly, C.A., Kerkhoff, A.J., Kirkup, D., Kitajima, K., Kleyer, M., Klotz, S., Knops, J.M.H., Kramer, K., Kühn, I., Kurokawa, H., Laughlin, D., Lee, T.D., Leishman, M., Lens, F., Lenz, T., Lewis, S.L., Lloyd, J., Llusià, J., Louault, F., Ma, S., Mahecha, M.D., Manning, P., Massad, T., Medlyn, B.E., Messier, J., Moles, A.T., Müller, S.C., Nadrowski, K., Naeem, S., Niinemets, Ü., Nöllert, S., Nüske, A., Ogaya, R., Oleksyn, J., Onipchenko, V.G., Onoda, Y., Ordoñez, J., Overbeck, G., Ozinga, W.A., Patiño, S., Paula, S., Pausas, J.G., Peñuelas, J., Phillips, O.L., Pillar, V., Poorter, H., Poorter, L., Poschlod, P., Prinzing, A., Proulx, R., Rammig, A., Reinsch, S., Reu, B., Sack, L., Salgado-Negret, B., Sardans, J., Shiodera, S., Shipley, B., Siefert, A., Sosinski, E., Soussana, J.-F., Swaine, E., Swenson, N., Thompson, K., Thornton, P., Waldram, M., Weiher, E., White, M., White, S., Wright, S.J., Yguel, B., Zaehle, S., Zanne, A.E., and Wirth, C. 2011. TRY - a global database of plant traits. Global Change Biology, 17:2905-2935. https://doi.org/10.1111/j.1365-2486.2011.02451.x

Kovar, J.B. 1982. Eine Blätter-Flora des Egerien (Ober-Oligozän) aus marinen Sedimenten der zentralen Paratethys im Linzer Raum (Österreich). Beiträge zur Paläontologie von Österreich, 9:1-209.

Kovar-Eder, J. 2016. Early Oligocene plant diversity along the Upper Rhine Graben: The fossil flora of Rauenberg, Germany. Acta Palaeobotanica, 56:329-440. https://doi.org/10.1515/ acpa-2016-0011

Kvaček, Z. and Teodoridis, V. 2011. The late Eocene flora of Kučlín near Bílina in North Bohemia revisited. Acta Musei Nationalis Pragae, Series B-Historia Naturalis, 67: 83-144.

Li, S.-F., Jacques, F.M.B., Spicer, R.A., Su, T., Spicer, T.E.V., Yang, J., and Zhou, Z.-K. 2016. Artificial neural networks reveal a high-resolution climatic signal in leaf physiognomy. 
Palaeogeography, Palaeoclimatology, Palaeoecology, 442:1-11. https://doi.org/10.1016/ j.palaeo.2015.11.005

Little, S.A., Kembel, S.W., and Wilf, P. 2010. Paleotemperature proxies from leaf fossils reinterpreted in light of evolutionary history. PLOS ONE, 5, e15161. https://doi.org/10.1371/ journal.pone.0015161

Mai, D. 1995. Tertiäre Vegetationsgeschichte Europas: Methoden und Ergebnisse. Spektrum Akademischer Verlag, Heidelberg, Germany.

Marine Species Traits editorial board 2017. Marine Species Traits. Accessed at http:// www.marinespecies.org/traits on 2017-01-09.

Miller, I., Johnson, K., and Ellis, B. 2005. Paleobotany Project. Retrieved June 12, 2017, from http://www.paleobotanyproject.org/

Mouton, J.-A. 1975. Florule élémentaire du Thanétien de Sézanne. Congrés National des Sociétés Savantes, 3:213-225.

Peppe, D.J., Royer, D.L., Cariglino, B., Oliver, S.Y., Newman, S., Leight, E., Enikolopov, G., Fernandez-Burgos, M., Herrera, F., Adams, J.M., Correa, E., Currano, E.D., Erickson, J.M., Hinojosa, L.F., Hoganson, J.W., Iglesias, A., Jaramillo, C.A., Johnson, K.R., Jordan, G.J., Kraft, N.J.B., Lovelock, E.C., Lusk, C.H., Niinemets, U., Penuelas, J., Rapson, G., Wing, S.L., and Wright, I.J. 2011. Sensitivity of leaf size and shape to climate: global patterns and paleoclimatic applications. New Phytologist, 190:724-739. https://doi.org/10.1111/j.14698137.2010.03615.x

R Core Development Team 2015. R: A language and environment for statistical computing. http://www.R-project.org/

Reich, P.B., Ellsworth, D.S., Walters, M.B., Vose, J.M., Gresham, C., Volin, J.C., and Bowman, W.D. 1999. Generality of leaf trait relationships: a text across six biomes. Ecology, 80:19551969.

Roßmäßler, E.A. 1840. Die Versteinerungen des Braunkohlensandsteins aus der Gegend von Altsattel in Böhmen (Elnbogener Kreises). Beiträge zur Versteinerungskunde, 1:42.

Royer, D.L., Peppe, D.J., Wheeler, E.A., and Niinemets, Ü. 2012. Roles of climate and functional traits in controlling toothed vs. untoothed leaf margins. American Journal of Botany, 99:915922. https://doi.org/10.3732/ajb.1100428

Royer, D.L., Sack, L., Wilf, P., Lusk, C.H., Jordan, G.J., Niinemets, Ü., Wright, I.J., Westoby, M., Cariglino, B., Coley, P.D., Cutter, A.D., Johnson, K.R., Labandeira, C.C., Moles, A.T., Palmer, M.B., and Valladares, F. 2007. Fossil leaf economics quantified: calibration, Eocene case study, and implications. Paleobiology, 33:574-589. https://doi.org/10.1666/07001.1

Saporta, G. 1868. Prodrome d'une flore fossile des travertins anciens de Sézanne. Mémoires de la Société Géologique de France, 2ème série VIII (3):299-437.

Saporta, G. and Marion, A.F. 1873. Essai sur l'état de la végétation à l'époque des marnes Heersiennes de Gelinden. Mémoire couronné de l'Académie Royale de Belgique, 37:1-94.

Saporta, G. and Marion, A.F. 1878. Révision de la flore Heersienne de Gelinden. Mémoire couronné de l'Académie Royal de Belgique, 41:1-112.

Su, T., Xing, Y.-W., Liu, Y.-S., Jacques, F.M.B., Chen, W.-Y., Huang, Y.-J., and Zhou, Z.-K. 2010. Leaf margin analysis: a new equation from humid to mesic forests in China. PALAIOS, 25:234-238. https://doi.org/10.2110/palo.2009.p09-129r

Thiébaut, M. 2002. A foliar morphometric determination of very fragmentary Salix remains from a late Miocene locality, Sé, western Hungary. Review of Palaeobotany and Palynology, 121:7790. https://doi.org/10.1016/S0034-6667(02)00074-X

Traiser, C., Roth-Nebelsick, A., Lange, J., and Kovar-Eder, J. 2015. MORPYHLL - database for acquisition of ecophysiologically relevant morphometric data of fossil leaves. Version 1.0; State Museum of Natural History Stuttgart. https://doi.org/10.17616/R3PQ07

Walther, H. and Kvaček, Z. 2007. Early Oligocene flora of Seifhennersdorf (Saxony). Acta Musei Nationalis Pragae, Series B Historia Naturalis 63:85-174.

Wappler, T., Currano, E.D., Wilf, P., Rust, J., and Labandeira, C.C. 2009. No post-Cretaceous ecosystem depression in European forests? Rich insect-feeding damage on diverse middle Palaeocene plants, Menat, France. Proceedings of the Royal Society of London B: Biological Sciences, 276:4271-4277. https://doi.org/10.1098/rspb.2009.1255

Wappler, T., Labandeira, C.C., Rust, J., Frankenhäuser, H., and Wilde, V. 2012. Testing for the effects and consequences of Mid Paleogene climate change on insect herbivory. PLoS ONE, 7, e40744. https://doi.org/10.1371/journal.pone.0040744 
Wilf, P. 1997. When are leaves good thermometers? A new case for Leaf Margin Analsysis. Paleobiology, 23:373-390. https://doi.org/10.1017/S0094837300019746

Wolfe, J.A. 1993. A method of obtaining climatic parameters from leaf assemblages. U.S. Geological Survey Bulletin, 2040:1-71.

Wolfe, J.A. and Spicer, R.A. eds. 1999. Fossil Leaf Character States: Multivariate Analysis. Geological Society Pubishing House, London.

Wolfe, J.A. and Upchurch, G.R. 1987. North American nonmarine climates and vegetation during the Late Cretaceous. Palaeogeography, Palaeoclimatology, Palaeoecology, 61:33-77. https:// doi.org/10.1016/0031-0182(87)90040-X

Wright, I.J., Reich, P.B., Cornelissen, J.H.C., Falster, D.S., Garnier, E., Hikosaka, K., Lamont, B.B., Lee, W., Oleksyn, J., Osada, N., Poorter, H., Villar, R., Warton, D.I., and Westoby, M. 2005. Assessing the generality of global leaf trait relationships. New Phytologist, 166:485496. https://doi.org/10.1111/j.1469-8137.2005.01349.x

Wright, I.J., Reich, P.B., Westoby, M., Ackerly, D.D., Baruch, Z., Bongers, F., Cavender-Bares, J., Chapin, T., Cornelissen, J.H.C., Diemer, M., Flexas, J., Garnier, E., Groom, P.K., Gulias, J., Hikosaka, K., Lamont, B.B., Lee, W., Lusk, C., Midgley, J.J., Navas, M.L., Niinments, Ü., Oleksyn, J., Osada, N., Poorter, H., Poot, P., Prior, L., Pyankov, V.I., Roumet, C., Thomas, S.C., Tjoelker, M.G., Veneklaas, E.J., and Villar, R. 2004. The worldwide leaf economics spectrum. Nature, 428:821-827. https://doi.org/10.1038/nature02403

Yang, J., Spicer, R.A., Spicer, T.E.V., Arens, N.C., Jacques, F.M.B., Su, T., Kennedy, E.M., Herman, A.B., Steart, D.C., Srivastava, G., Mehrotra, R.C., Valdes, P.J., Mehrotra, N.C., Zhou, Z.-K., and Lai, J.-S. 2015. Leaf form-climate relationships on the global stage: an ensemble of characters. Global Ecology and Biogeography, 24:1113-1125. https://doi.org/ 10.1111/geb.12334 


\section{APPENDIX 1}

Web page of the MORPHYLL database http://www.morphyll.naturkundemuseum-bw.de (Traiser et al., 2015). 